\title{
KAJIAN KEGAGALAN KAMPANYE PERIKLANAN EXPERIENTIAL SOLIDARITAS SOCIAL DISTANCING COVID-19 MCDONALD'S BRAZIL
}

\begin{abstract}
Alvanov Z. Mansoor
Abstrak: Pewaralaba McDonald's Brazil memublikasikan kampanye experiential solidaritas gerakan social distancing untuk menghambat pandemi Covid-19 pada 20 Maret 2020. Awalnya kampanye tersebut mendapat apresiasi positif, namun muncul sejumlah apresiasi negatif dari netizen media sosial global yang mengakibatkan McDonald's menarik semua materi kampanye tersebut sambil meminta maaf. Kampanye ini dikaji secara deskriptif eksplanatif sebagai sebuah pembelajaran dalam bidang desain komunikasi visual, khususnya perancangan experiential marketing yang memanfaatkan identitas merek. Didapatkan bahwa strategi kampanye yang disusun melalui sejumlah modul pengalaman relevan dengan alasan rasional yang dibangun, akan tetapi tidak membangun empati atau ada kesenjangan pada aspek emosional. Selain itu terdapat kesenjangan informasi atas layanan dengan ekspektasi serta persepsi masyarakat terhadap merek dan kampanye yang dilaksanakan. Pertimbangan relasi antara pemanfaatan elemen identitas dan merek dengan persepsi dan ekspektasi akan kinerja merek harus disusun dan dipetakan dengan jelas sebelum merancang sebuah kampanye dengan strategi experiential marketing.
\end{abstract}

Kata kunci: experiential marketing, McDonald's, social distancing, brand identity, Covid-19

\section{Latar Belakang}

Pewaralaba independen McDonald's dari Brazil, yaitu Arcos Dorados pada tanggal 23 Maret 2020 merencanakan untuk menutup seluruh gerai McDonald's yang dikelolanya untuk mengantisipasi meluasnya penyebaran infeksi Covid-19. Aktivitas tersebut akan disertai dengan pengalihan layanan makan di tempat menjadi layanan bawa pulang (take away),

Alvanov Z. Mansoor adalah staf pengajar pada Fakultas Seni dan Desain Institut Teknologi Bandung, Bandung. layanan hantaran (delivery service), dan layanan drive through (Adsoftheworld, 2020). Pengalihan layanan tersebut diinisasi dengan kampanye periklanan pengalaman (experiential campaign) melalui media sosial yang dikerjakan oleh Agen periklanan DPZ\&T, Brazil. DPZ\&T dalam mengampanyekan aktivitas tersebut mengembangkan ide kreatif berbasis gerakan karantina diri (self isolation) dan penerapan jarak sosial (social

e-mail : alvanov.mansoor@itb.ac.id 
distancing) dengan judul "Separated for a moment to always be together" dalam bahasa Portugis melalui penanda visual berupa pemisahan 2 lengkungan ikoniknya membentuk huruf $M$ sebagai inisial merk McDonald's (lihat gambar 1). Pengubahan logo ini bersifat sementara sebagai sebuah kampanye solidaritas yang berempati pada pelanggan McDonald's yang harus mengisolasi diri dan keluarganya untuk tidak beraktivitas di luar rumah. Kampanye ini dirilis serentak melalui berbagai kanal media sosial McDonald's Brazil seperti Twitter, Instagram, dan Facebook (Ads of The World, 2020; Hollan, 2020).

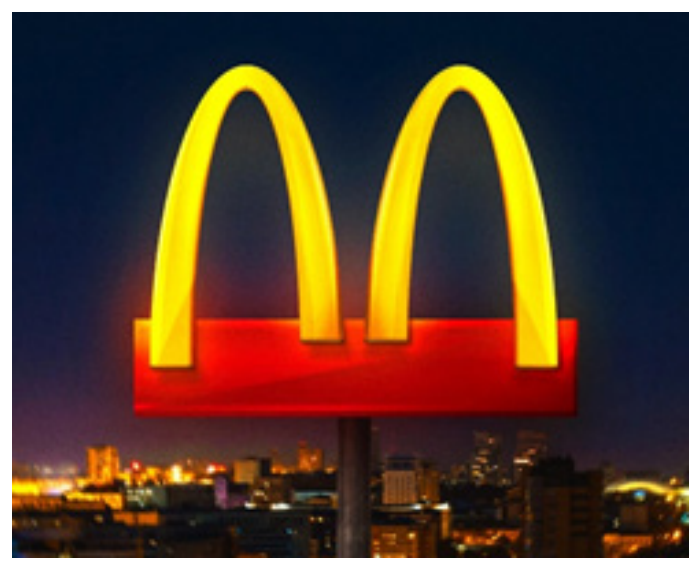

Gambar 1. Logo McDonald's yang diubah (Sumber: ads of the world, 2020)

Kampanye McDonald's Brazil yang mendukung gerakan penerapan jarak sosial sebenarnya tidak berjalan sendirian. Terdapat sejumlah perusahaan yang juga melakukan kampanye dengan konsep sejenis seperti perusahaan minuman berkarbonasi Coca Cola, perusahaan otomotif Audi, perusahaan yang mengelola online marketplace di Argentina, Mercado Libre, dan produsen makanan ringan Israel Keef Kef (Adsoftheworld, 2020). Gerakan solidaritas tersebut menurut Coggan (2020) terinspirasi oleh ide kreatif dari Jure Tovrljan yang disampaikannya dalam akun behance.net miliknya pada 14 Maret 2020. Jure Tovrljan merekreasi sejumlah logo ikonik sebagai gagasan bagaimana logo-logo tersebut seharusnya terlihat dalam masa sulit(PandemiCovid-19) sebagai aksi dukungan terhadap penerapan jarak sosial dan karantina diri (Tovrljan, 2020).

Ide kreatif yang dimunculkan oleh Biro periklanan DPZ\&T mirip dengan salah satu ide Tovrljan, yaitu dengan memberi jarak antar elemen dalam logo-logo perusahaan. Pada awalnya kampanye solidaritas ini mendapatkan apresiasi positif di seluruh dunia dengan menuai ratusan ribu likes di facebook (GMA News 2020). Akan tetapi hanya dalam beberapa hari, kampanye periklanan pengalaman solidaritas penerapan jarak sosial Covid-19 McDonald's Brazil mendapat kritik keras dari netizen. Gelombang apresiasi negatif muncul melalui berbagai akun Twitter dan Instagram, yang menganggap kampanye solidaritas yang dilakukan oleh McDonald's Brazil tersebut tidak berempati kepada masyarakat yang terdampak wabah Covid-19, dan oportunis demi meraih penghargaan, dan tidak memberikan dampak signifikan kepada pihak-pihak yang dirugikan (gambar 2).

Bahkan salah satu senator US dari partai Demokrat Bernie Sanders, mengecam kampanye tersebut dan menyarankan agar pihak McDonald's lebih baik memberikan honor cuti (sakit) kepada pegawainya yang dirumahkan. Adapun cuitan Bernie Sanders tersebut mendapatkan dukungan sebanyak 397 ribu dan diperbincangkan oleh lebih dari 65 ribu pengguna Twitter lain. Kecaman-kecaman tersebut mengakibatkan pihak McDonald's Brazil menghapus dan menarik kembali seluruh materi kampanye tersebut di semua kanal media sosialnya sambil meminta maaf kepada publik (Diaz, 2020; Leow, 2020; Walansky, 2020).

Artikel ini menelaah kesalahan apa yang dilakukan oleh McDonald's Brazil dalam kampanyenya agar dapat menjadi sebuah proses pembelajaran kreatif bagi 

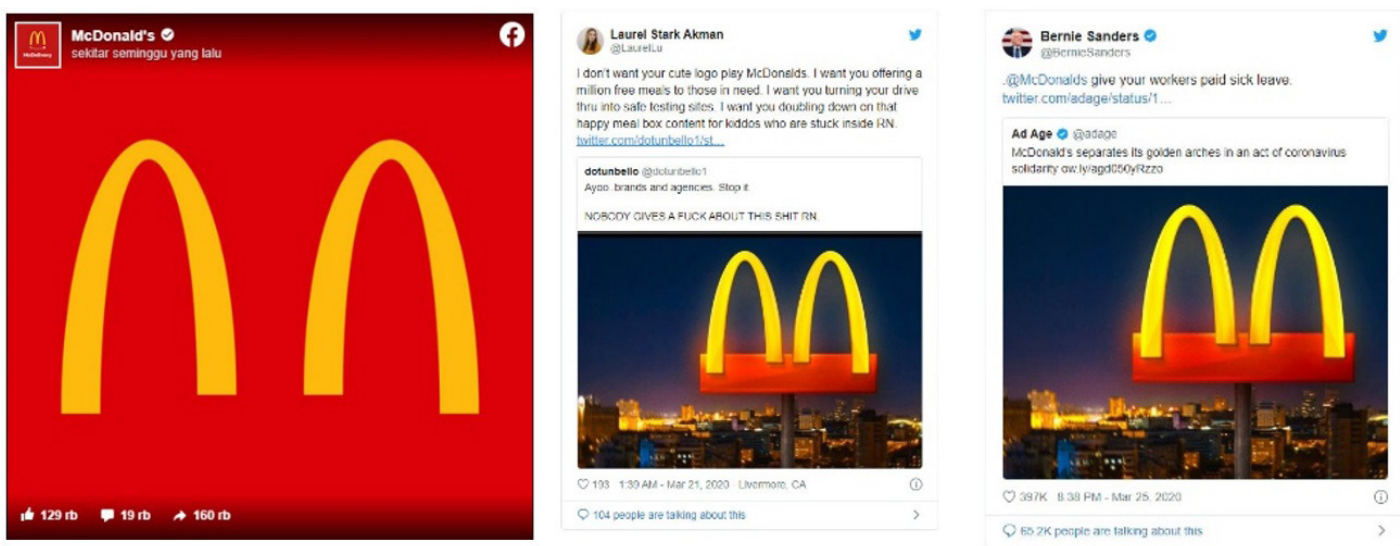

Gambar 2. Dukungan positif di akun Facebook McDonald's Brazil (kiri) \& apresiasi negatif netizen (tengah \& kanan).

(Sumber: (kiri) GMA News, 2020, (tengah) Piper, 2020, \& (kanan) Diaz, 2020).

para praktisi kreatif periklanan. kampanye periklanan pengalaman solidaritas penerapan jarak sosial Covid-19 McDonald's Brazil ini dikaji dalam aspek konsep identitas atau logo dan merk, serta pemasaran pengalaman (experiential marketing) dalam kerangka komunikasi periklanan dalam bidang desain komunikasi visual.

\section{Metode Penelitian}

Penelitian ini adalah penelitian kualitatif deskriptif eksplanatif yang memaparkan struktur dan elemen komunikasi pendukung kampanye periklanan pengalaman solidaritas penerapan jarak sosial Covid-19 McDonald's Brazil secara deskriptif, kemudian menelaah relasi antar elemen tersebut dengan konteks sosialnya untuk mendapatkan kejelasan sebab-akibat atas berbagai apresiasi yang muncul (Tajibu, 2013). Adapun metode pengumpulan data dalam penelitian ini dilakukan melalui studi literatur dan observasi. Data yang dikumpulkan tersebut sebelum dianalisis struktur informasinya, dilakukan triangulasi data atau pengecekan silang untuk menguji validitas dan objektivitas informasi dalam data yang dikumpulkan. Kemudian setelah struk- tur kampanye tersebut terpetakan, tahap berikutnya adalah memetakan korelasinya dengan konteks, persebaran informasi, interaksi sosial serta tujuan dan sasaran kampanye eksperiensial. Pada akhirnya, penelitian ini akan menghasilkan rekomendasi mengenai perancangan kampanye pemasaran pengalaman dalam kerangka komunikasi periklanan.

\section{Identitas Merek}

Menurut Wheeler (2017), identitas merek (Brand Identity) adalah sesuatu yang nyata (tangible) dan menarik bagi indera. Identitas merek memicu pengakuan, memperkuat diferensiasi, dan membuat gagasan dan nilai dapat dimengerti. Adapun elemen yang penting dalam identitas merek adalah makna dari merek, diferensiasi yang menjadi keunikan, ketahanan dan lentur terhadap perubahan atau dinamika di masyarakat (Jain, 2017). Dalam beberapa kasus, masyarakat khususnya konsumen cenderung membentuk pendapat dan persepsi dari sebuah merek sebelum mereka mengetahui siapa dan apa yang merepresentasikan melalui seperangan identitas merek, yaitu simbol, logo, warna, slogan, 
dan jingle atau alunan musik atau lagu.

Dalam komunikasi abad 21, media sosial merupakan salah satu lini media yang penting untuk menjaga kepercayaan dan loyalitas terhadap merek (Ekhlassi, Moghadam, \& Adibi, 2018). Salah satu upaya yang dapat dilakukan adalah membangun brand storytelling untuk menjaga opini dan persepsi positif pengguna media sosial terhadap merek.

\section{Kampanye Experiential}

Kampanye experiential merupakan aktivitas dalam experiential marketing atau pemasaran pengalaman adalah proses mengidentifikasi aspirasi kepuasan pelanggan dan memenuhi kebutuhan tersebut melalui komunikasi interaktif yang membawa merek dan nilai ke dalam kehidupan mereka (Smilansky, 2018). Menurut Schmitt (2011), untuk membangun sebuah pemasaran pengalaman, dibutuhkan Strategic Experience Modules (SEMs) yang dibangun melalui
Experience Producers (ExPros). SEMs terdiri atas Sense (Panca Indera), Feel (Perasaan), Think (Pikiran), Act (tindakan), dan Relate (hubungan). Adapun ExPros meliputi komunikasi, identitas visual, kehadiran produk/jasa, kerjasama merek, lingkungan spasial, laman daring, dan manusia (baik sebagai pembuat pesan maupun sebagai penerima pesan). Terdapat 3 kunci pokok (Aryana, 2019) untuk mengidentifikasikan aspirasi kepuasan pelanggan sebelum mengembangkan SEMs dan ExPros untuk membangun strategi komunikasi pemasaran pengalaman, yaitu, (1) pengalaman pelanggan dalam berinteraksi dengan merek, (2) pola konsumsi terhadap merek dalam konteks kausalitas secara luas sampai pada tataran makna konsumsi merek di benak konsumen bila diperlukan, dan (3) keputusan rasional dan emosional dalam interaksi dengan merek.

Dalam mengomunikasikan dan mempersuasi khalayak sasaran, pemasaran pengalaman harus didukung oleh aktivitas komunikasi periklanan (Terkan, 2014).

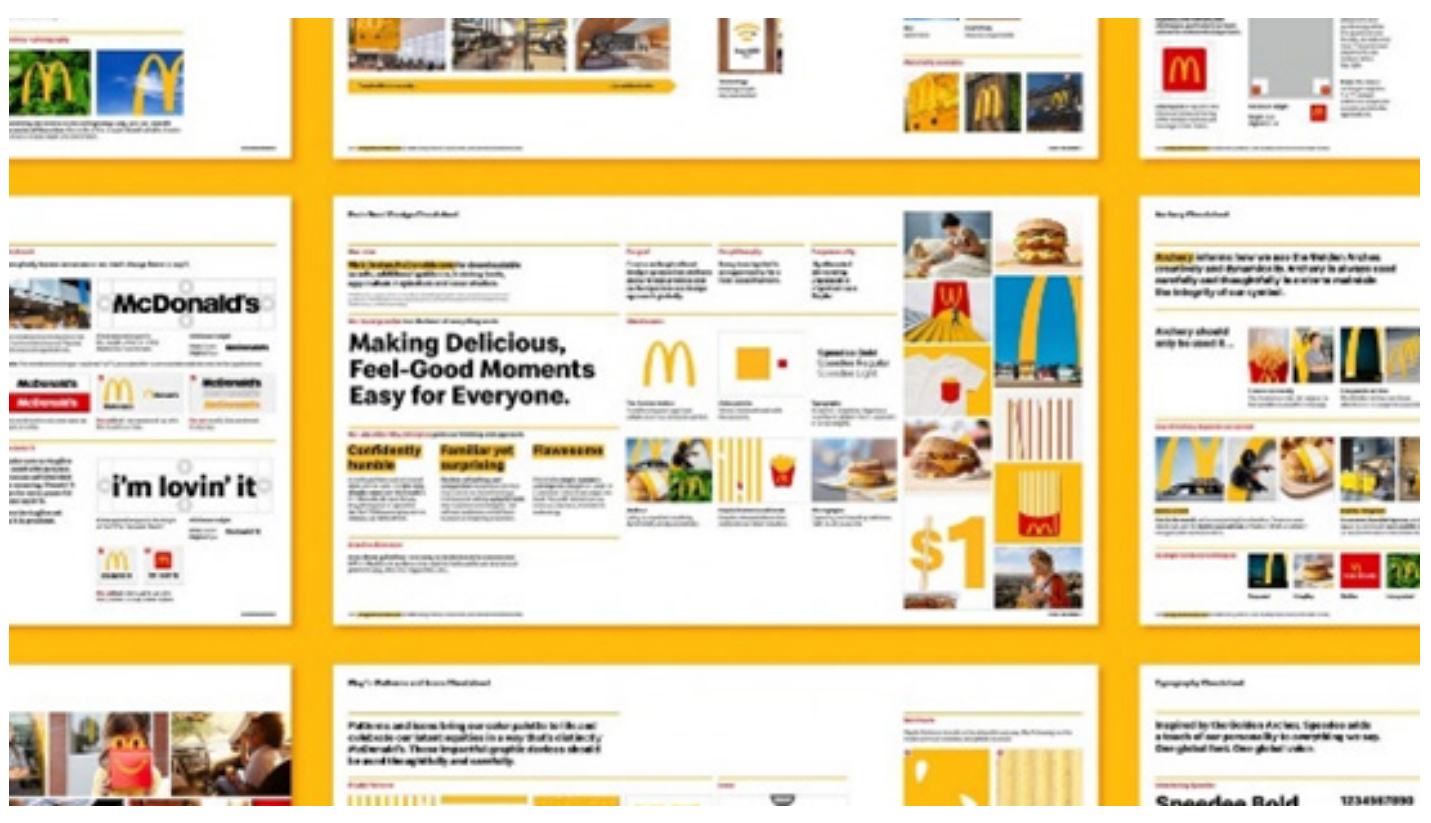

Gambar 3. Sistem identitas visual merek McDonald's karya biro Desain Grafis Turner Duckworth (Sumber: Brewer, 2019) 


\section{Identitas Merek McDonald's}

Sebagai sebuah perusahaan waralaba global, McDonald's membangun jejaring dengan berbagai pewaralaba skala nasional sebagai pemegang lisensi yang memiliki aturan ketat terkait pengelolaan merek dan identitas. Beberapa identitas visual yang dikenali dari McDonald's adalah 2 buah lengkung berwarna kuning emas, dasar latar berwarna merah atau kuning, ilustrasi sejumlah produk khas McDonald's seperti french fries dan burger Big Mac (Turner Duckworth, 2019). Pengembangan sistem identitas merek McDonald's terkini dikembangkan oleh sebuah biro desain grafis Turner Duckworth dengan memperhatikan aspek skala kecil dan tetap memberikan peluang eksploratif pada skala global (Brewer, 2019). Dalam sistem yang dirancang oleh Turner Duckworth, terdapat kemungkinan eksplorasi dinamis dari penerapan logo seperti pemutarbalikan lengkungan emas yang diterapkan dalam kampanye solidaritas International Women's day pada tahun 2019 dan pemotongan lengkung emas pada trophy kompetisi Feel Good Marketing Awards 2019 yang diselenggarakan oleh McDonald's dalam ajang Cannes khusus untuk biro marketing, desain grafis, dan periklanan yang merancang kampanye komunikasi pemasaran McDonald's di seluruh dunia (Schultz, 2019).

Dalam pengembangan sistem identitas tersebut, hampir semua elemen visual dalam logo McDonald's diekstrak-si menjadi elemen yang lebih dinamis dan fundamental, yaitu aspek lengkung, warna merah, dan khususnya warna kuning emas. Dengan menggunakan elemen grafis yang berasal dari simplifikasi objek khas McDonald's dan logo menjadikan logo secara rigid menjadi tidak signifikan keberadaannya. Kehadiran merek McDonald's dibangun dengan kemunculan elemen-elemen grafis yang signifikan kaitannya dengan identitas dan produk McDonald's secara kontinu di berbagai tem- pat serta exposure media secara global.

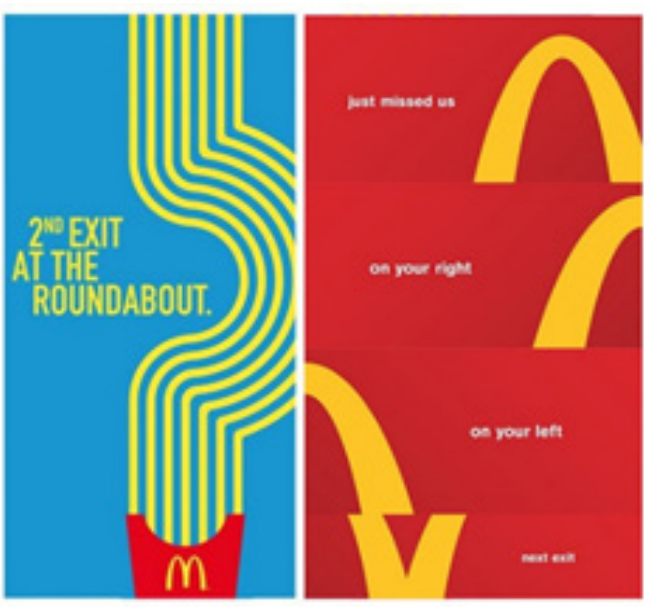

Gambar 4. Implementasi logo menjadi elemen identitas

(Sumber: (kiri) McAteer, 2019, (kanan) Czarny, 2019)

\section{Kampanye Periklanan Pen- galaman Solidaritas Pener- apan Jarak Sosial Covid-19 MeDonald's Brazil}

Kampanye ini bertujuan untuk meningkatkan kesadaran masyarakat Brazil mengenai perlunya untuk tetap di rumah dan penerapan jarak sosial demi menghambat penyebaran penyakit Covid-19. Adapun simbolisasi dukungan atas aktivitas tersebut adalah dengan memberi jarak antara 2 lengkung ikonik McDonald's yang awalnya membentuk huruf 'M.' Kampanye periklanan pengalaman solidaritas Covid-19 McDonald's Brazil ini dirancang oleh biro periklanan DPZ\&T dan dirilis pada berbagai kanal media sosial resmi McDonald's seperti Facebook, Twitter, dan Instagram.

Aktivitas lainnya adalah meniadakan layanan makan di tempat dan memaksimalkan layanan antar, layanan drive through, serta layanan bawa pulang. Berdasarkan hasil peng-amatan penulis pada beberapa sumber, tidak ada aktivitas atau implementasi lainnya dari kampanye 
tersebut.

Tabel 1. Experience Producers Experiential Marketing McDonald's

\begin{tabular}{|c|c|}
\hline ExPros & Implementasi \\
\hline $\begin{array}{r}\text { Komuni- } \\
\text { kasi }\end{array}$ & $\begin{array}{l}\text { Solidaritas perusahaan } \\
\text { terhadap fenomena penye- } \\
\text { baran penyakit Covid-19 dan } \\
\text { mendukung gerakan pene- } \\
\text { rapan jarak sosial di Brazil, } \\
\text { serta pengubahan layanan }\end{array}$ \\
\hline $\begin{array}{r}\text { Identitas } \\
\text { Visual }\end{array}$ & $\begin{array}{l}\text { Pemisahan Lengkung ikonik } \\
\text { McDonald's sebagai simbol } \\
\text { penerapan jarak sosial }\end{array}$ \\
\hline $\begin{array}{r}\text { Kehadiran } \\
\text { Produk }\end{array}$ & $\begin{array}{l}\text { Tidak ada produk khusus } \\
\text { yang ditawarkan }\end{array}$ \\
\hline $\begin{array}{r}\text { Kerjasama } \\
\text { Merek }\end{array}$ & Biro Periklanan DPZ\&T \\
\hline $\begin{array}{l}\text { Lingkung- } \\
\text { an Spasial }\end{array}$ & $\begin{array}{l}\text { Brazil, khususnya gerai } \\
\text { McDonald's yang dikelola } \\
\text { oleh Arcos Dorados }\end{array}$ \\
\hline $\begin{array}{l}\text { Laman } \\
\text { Daring }\end{array}$ & $\begin{array}{l}\text { Dibangun melalui kanal } \\
\text { media sosial McDonald's, } \\
\text { menyebar ke seluruh dunia }\end{array}$ \\
\hline $\begin{array}{l}\text { Manusia- } \\
\text { produsen }\end{array}$ & $\begin{array}{l}\text { Karyawan yang sakit } \\
\text { dirumahkan, lainnya tetap } \\
\text { bertugas di gerai }\end{array}$ \\
\hline $\begin{array}{l}\text { Manusia- } \\
\text { konsumen }\end{array}$ & $\begin{array}{l}\text { Harus beralih ke layanan } \\
\text { antar, drive-thru \& bawa } \\
\text { pulang }\end{array}$ \\
\hline
\end{tabular}

Berdasarkan hasil pemetaan Experience Producers (ExPros) dari kampanye periklanan pengalaman solidaritas Covid-19 McDonald's Brazil, maka dapat dipetakan pula ekspektasi strategic mod- ules (SEMs) yang direncanakan oleh McDonald's Brazil dan DPZ\&T yaitu seperti yang terlihat pada tabel 2.

Tabel 2. Strategic Modules Experiential Marketing McDonald's

\begin{tabular}{|c|c|}
\hline SEMs & Elkspektasi \\
\hline $\begin{array}{l}\text { Sense/ } \\
\text { Indera }\end{array}$ & $\begin{array}{l}\text { Gagasan penerapan jarak } \\
\text { sosial \& isolasi diri melalui } \\
\text { pemisahan logo ditangkap } \\
\text { oleh masyarakat }\end{array}$ \\
\hline Feel/Rasa & $\begin{array}{l}\text { McDonald's berempati } \\
\text { kepada masyarakat yang } \\
\text { harus mengisolasi diri }\end{array}$ \\
\hline $\begin{array}{r}\text { Think/ } \\
\text { Pemikiran }\end{array}$ & $\begin{array}{l}\text { Bahwa McDonald's (Brazil) } \\
\text { mendukung gerakan } \\
\text { penerapan jarak sosial \& } \\
\text { isolasi diri }\end{array}$ \\
\hline Relate & $\begin{array}{l}\text { McDonald's ingin masya- } \\
\text { rakat dapat mengaitkan } \\
\text { pemisahan logo dengan } \\
\text { kondisi pandemi Covid-19 } \\
\text { sebagai bentuk empati }\end{array}$ \\
\hline (Expected) & Masyarakat mengapresiasi \\
\hline & $\begin{array}{l}\text { positif kampanye } \\
\text { McDonald's. Masyarakat } \\
\text { beralih ke layanan antar, } \\
\text { bawa pulang dan drive in }\end{array}$ \\
\hline
\end{tabular}

Kampanye periklanan pengalaman solidaritas Covid-19 McDonald's Brazil tidak berjalan lancar, bahkan harus dibatalkan dan McDonald's meminta maaf kepada publik serta menarik seluruh materi kampanye tersebut sebelum mencapai hitungan 1 minggu. Bila ditelaah melalui relasi antara ExPros dengan SEMs, tidak terlihat adanya kesenjangan 


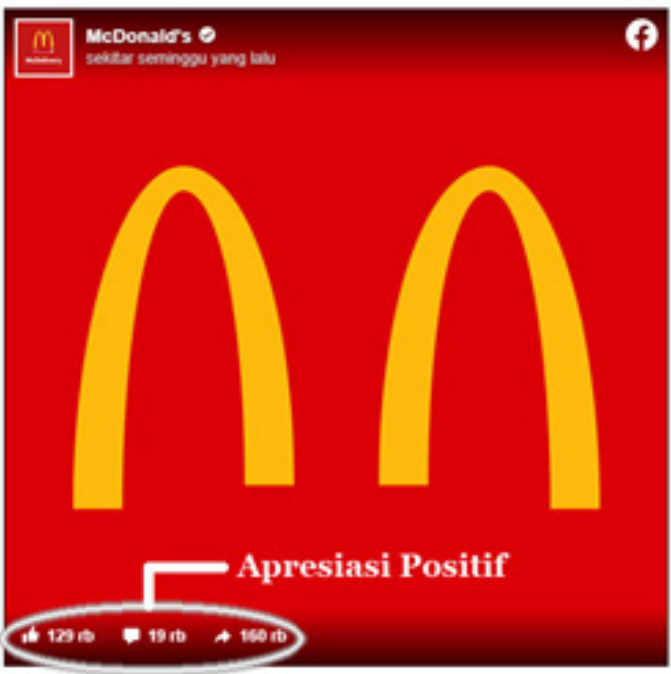

Gambar 5. Apresiasi positif terhadap kampanye periklanan pemasaran pengalaman solidaritas penerapan jarak sosial Covid-19 McDonald's Brazil.

antara kegiatan dengan tujuan. Kampanye tersebut awalnya menuai apresiasi positif yang ditandai dengan jumlah apresiasi positif di berbagai akun media sosial McDonald's.
Akan tetapi gelombang protes bermunculan dan dari sejumlah netizen serta menimbulkan gelombang ketidak-puasan dari masyarakat berbagai kalangan. Pada gambar 6 dapat dilihat durasi waktu antara publikasi kampanye (tanggal 20 maret 2020) dengan protes atau opini negatif yang muncul hanya berselang 1 hari (tanggal 21 Maret 2020). Apresiasi negatif ini kemudian meluas dan merembet sampai salah satu politikus US ikut memunculkan opini negatif (Bernie Sanders ikut memberi opini, gambar 6).

\section{Komunikasi Periklanan Global vs Layanan Regional}

Arcos Dorados selaku pewaralaba McDonald's di Brazil, mempercayakan perancangan kampanye periklanan pengalamannya kepada biro periklanan DPZ\&T dengan lingkup komunikasi negara Brazil. Biro periklanan DPZ\&T kemudian mengembangkan konsep pemisahan logo McDonald's sebagai ujung tombak komunikasi dalam kampanye periklan-an pengalaman solidaritas pen-

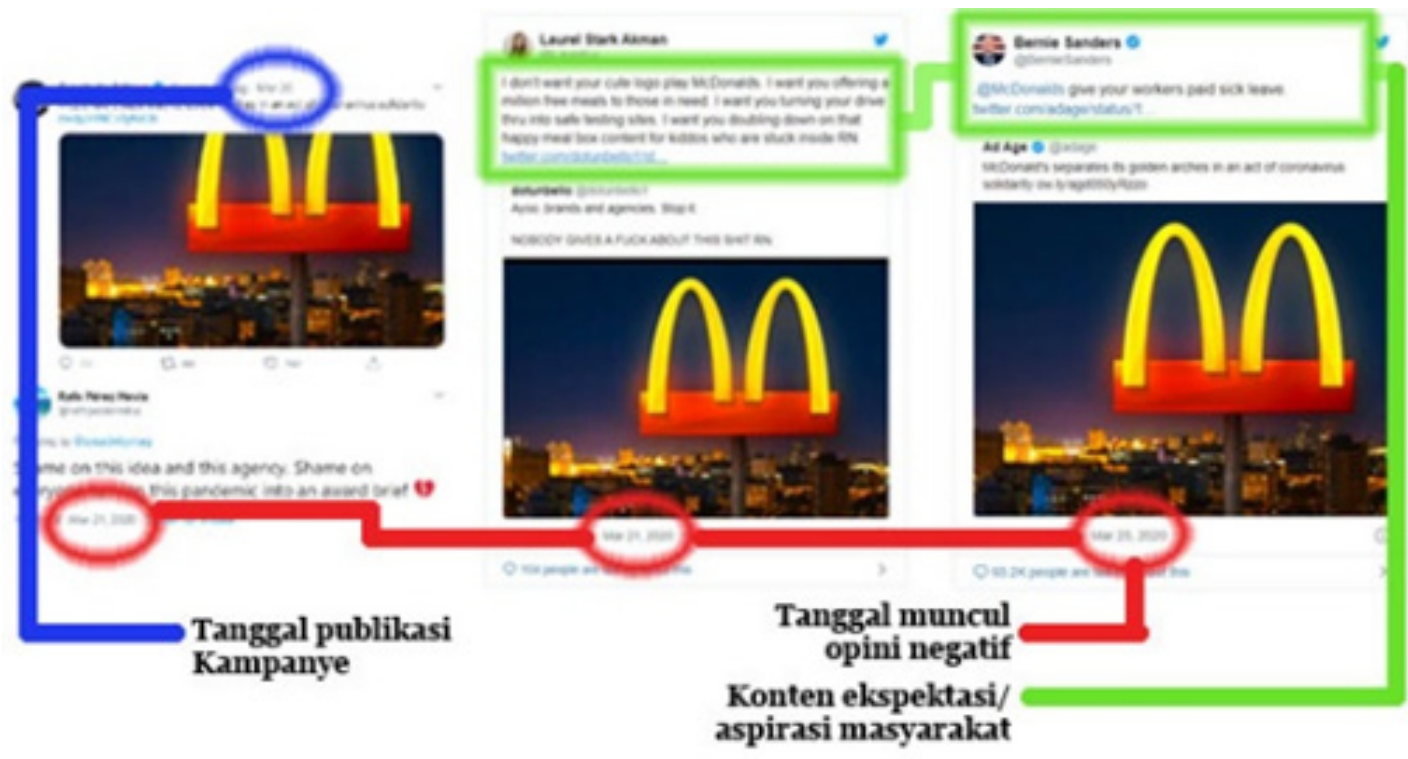

Gambar 6. Rentang waktu antara publikasi kampanye dengan munculnya opini negatif netizen 
erapan jarak sosial Covid-19 McDonald's Brazil dengan lingkup aktivitas di Brazil. Akan tetapi konten kampanye periklanan tersebut meluas ke seluruh dunia, karena dipublikasikan melalui kanal media sosial McDonald's yang kemudian dikutip dan diapresiasi oleh berbagai media daring global. Konteks regional Brazil tidak tertangkap oleh masyarakat internasional dan dianggap sebagai kampanye dari McDonald's lintas negara atau global. Ada kesenjangan informasi antara aktivitas dan layanan kampanye yang sebenarnya hanya berlaku di Brazil, tetapi diinterpretasikan meluas sampai ke Amerika Serikat (US). Bernie Sanders, politikus Amerika Serikat beropini dengan konteks aktivitas dalam wilayah Amerika Serikat, karena pada waktu yang berdekatan dengan kampanye tersebut, pihak McDonald's Amerika Serikat sedang melakukan lobi politik mengenai penyesuaian nilai honor untuk pegawainya yang dirumahkan dalam konteks pandemi Covid-19.

\section{Layanan vs Harapan Kon- sumen}

Tidak ada informasi lebih detil dari dihentikannya layanan makan di tempat dan beralih ke layanan drive through, bawa pulang, dan layanan antar McDonald's terkait kampanye periklanan pengalaman solidaritas Covid-19 McDonald's Brazil ini. Akan tetapi dari sejumlah respons netizen, mereka lebih mengharapkan adanya paket-paket spesial yang baru sebagai 'kompensasi' dari dihentikannya layanan makan di tempat. Ada kemungkinan menu khusus tersebut masih dalam pengembangan oleh tim pewaralaba, akan tetapi karena tidak ada informasi lebih lanjut, masyarakat (Brazil dan Amerika Serikat) berasumsi bahwa kampanye tersebut hanyalah upaya 'menunggangi' pandemi Covid-19 tanpa ada nilai sosial atau solidaritas yang lebih jauh. Belajar dari kasus kampanye solidaritas McDonald's di Bra- zil tersebut, McDonald's Amerika Serikat merilis serial iklan televisi dan juga disebar melalui media sosial yang menekankan pada layanan non makan di tempat plus penawaran paket dan menu khusus (Wohl, 2020). Dapat dikatakan, salah satu aspek yang membuat McDonald's sebagai salah satu waralaba makanan siap saji yang selalu diminati oleh konsumennya adalah adaptif terhadap selera konumen, konteks sosial budaya negara, dan konteks tradisi serta ritual dari masyarakat kontemporer di berbagai belahan dunia (Racoma, 2019).

\section{Rasional vs Emosional da- lam Keputusan Konsumen}

Kampanye periklanan pengalaman solidaritas Covid-19 McDonald's Brazil merupakan sebuah adaptasi rasional dan simbolik terhadap konteks pandemi Covid-19. Dengan pengubah-suaian identitas merek sebagai ujung tombak komunikasi periklanan dalam kampanye. Akan tetapi kebutuhan emosional dari konsumen terabaikan dengan tidak atau belum dilakukannya adaptasi pada layanan secara emosional. Sejumlah tayangan di media sosial muncul dari netizen yang tertekan karena aktivitas sosialnya menjadi sangat terbatas, khususnya aktivitas untuk bereksplorasi dalam berbagai hal dan salah satunya adalah sosialisasi terkait kuliner. Walaupun terdapat sejumlah riset dan kajian yang memberikan rekomendasi kepada masyarakat terkait bagaimana menghadapi pandemi Covid-19, stress tetap terjadi. Salah satu bentuk efek samping dari stress adalah makan berlebih akibat meningkatnya hormon cortisol (Harvard health Publishing, 2020). Bagi pemerhati dan masyarakat yang sadar akan kesehatan, hal tersebut harus disiasati dan dihindari secara rasional. Akan tetapi bagi mayoritas manusia, tanpa disadarinya makan menjadi sebuah aktivitas pereda stress yang 
efektif secara emosional (Astuti dan Wulandari, 2020). Hal ini dapat dilihat peluang bagi pebisnis di industri makanan seperti McDonald's. Oleh karena itu, perilaku emosional masyarakat akibat pandemi Covid-19 dapat menjadi bahan evaluasi untuk merancang strategi kampanye per-iklanan pengalaman yang tepat (lebih dari sekedar menunjukkan solidaritas) bagi pelaku bisnis makanan dan minuman serta bisnis terkait lainnya.

\section{Kesimpulan}

McDonald's mengembangkan strategi komunikasi globalnya dengan mengeksploitasi elemen identitas visual. Eksplorasi tersebut dapat termasuk aktivitas yang mengubah elemen statis dalam logo menjadi lebih dinamis sebagai elemen identitas. Dalam 5 tahun terakhir, logo dan identitas visual lainnya dieksploitasi dalam berbagai kampanye periklanan pemasaran maupun per-iklanan sosial McDonald's di berbagai negara di dunia.

Dalam kampanye periklanan pengalaman solidaritas penerapan jarak sosial Covid-19 McDonald's di Brazil, biro periklanan DPZ\&T Brazil mengubah-suai elemen identitas sebagai ujung tombak komunikasi persuasi. Konten pengubah-suaian identitas visual tersebut disertai pesan kampanye dirillis melalui berbagai kanal media sosial McDonald's Brazil yang kemudian dikutip dan dipublikasikan secara global oleh berbagai media massa daring.

Berdasarkan pemetaan aspek Experience Producers serta relasinya dengan Strategic Modules yang diimplementasikan, seharusnya tidak ada resistensi karena berkesesuaian. Akan tetapi apresiasi negatif yang muncul disebabkan karena McDonald's gagal membaca aspirasi kepuasan pelanggan. Aspirasi kepuasan pelanggan waralaba McDonald's tidak sekedar berempati dengan menunjuk- kan solidaritas semata. Telaah atas kunci pokok yang menentukan bagaimana merancang sebuah kampanye periklanan pengalaman penerapan jarak sosial Covid-19 McDonald's Brazil tersebut menunjukkan bahwa McDonald's Brazil gagal meraih peluang bisnis karena menggunakan pendekatan rasional ketimbang pendekatan emosional masyarakat. Ide kreatif dalam mengubahsuai elemen identitas sebagai pesan persuasi harus dikembangkan sampai pada tahap implementasi lapangan. Hal tersebut diperlukan sebagai kesinambungan untuk mem-persuasi khalayak sasaran dalam sebuah perancangan komunikasi persuasif periklanan, khususnya periklanan yang menekankan pengalaman khalayak sasaran seperti pemasaran pengalaman.

\section{Referensi}

Ads of The World. (2020, March). McDonald's: Separated for a moment to always be together. Retrieved March 29, 2020, from https://www.adsoftheworld.com/media/experiential/ mcdonalds_separated_for_a_moment_to_always_be_together

Ads of The World. (2020, March). COVID-19 Ads. Retrieved March 29, 2020, from https://www.adsoftheworld.com/collection/covid19_ads

Aryana, I. P. (2019). Experiental Marketing Sebagai Pendekatan Dalam Memahami Konsumen, Wiraniaga: Membangun Jaringan Penjualan. Surabaya: Narotama University Press.

Astuti, D., \& Wulandari, D. (2020). Stres dan Perilaku Merokok Berhubungan dengan Kejadian Gastritis. Jurnal Ilmiah Permas: Jurnal Ilmiah STIKES Ken-dal, 10(2), 213-222. Retrieved from http://journal.stikeskendal. ac.id/index.php/PSKM/article/ 
view/716

Brewer, J. (2019, July 25). Behind the McDonald's redesign: from the Speedee typeface to the Archery logo system. Retrieved April 7, 2020, from https://www.itsnicethat.com/articles/ turner-duckworth-redesign-mcdonalds-branding-visual-identity-graphic-design-250719

Coggan, G. (2020, March 19). Iconic logos reimagined for the age of coronavirus. Retrieved March 30, 2020, from https://www.creativebloq.com/news/ logos-coronavirus

Czarny, B. (2019, November 19). Loca-tion data is improving $\mathrm{OOH}$ ads in starkly different ways. Retrieved April 7, 2020, from https://www.campaignlive.com/article/location-data-improving-ooh-ads-starkly-different-ways/1594795

Diaz, A.-C. (2020, March 25). McDon-ald's rethinks its COVID-inspired golden arches tweak. Retrieved May 6, 2020, from https://www.chicagobusiness. $\mathrm{com} /$ marketing-media/mcdonaldsrethinks-its-covid-inspired-goldenarches-tweak

Diaz, A.-C. (2020, March 20). McDonald's removes its coronavirus message featuring separated golden arches. Retrieved March 28, 2020, from https:// adage.com/creativity/work/mcdonalds-separated/2245431

Ekhlassi, A., Moghadam, M. N., \& Adibi, A. M. (2018). Building Brand Identity in the Age of Social Media. Advances in Marketing, Customer Relationship Management, and E-Services. doi: 10.4018/978-1-5225-5143-0

GMA News Online. (2020, March 20). LOOK: McDonald's Brazil tweaks logo to practice 'social distancing'.
Retrieved March 28, 2020, from https://www.gmanetwork.com/ news/hashtag/content/730626/mcdonald-s-brazil-tweaks-logo-to-practice-social-distancing/story/

Harvard Health Publishing. (2020). How stress can make us overeat. Retrieved April 10, 2020, from https://www. health.harvard.edu/healthbeat/howstress-can-make-us-overeat

Hollan, M. (2020, March 23). McDonald's changes Golden Arches logo amid coronavirus outbreak to demonstrate social distancing. Retrieved March 28, 2020, from https://www. foxnews.com/food-drink/mcdonalds-logo-coronavirus-outbreak

Jain, R. (2017). Basic Branding Concepts: Brand Identity, Brand Image and Brand Equity. International Journal of Sales \& Marketing Management Research and Development, 7(4), 1-8. doi: 10.24247/ijsmmrdaug20171

McAteer, O. (2019, August). Ad of the Week: McDonald's dominates sim-plicity. Retrieved April 7, 2020, from https://www.campaignlive. com/article/ad-week-mcdonalds-dominates-simplicity/1592683

Piper, D. (2020, March 25). McDonald's apologises after tasteless logo change. Retrieved March 29, 2020, from https://www.creativebloq. com/news/mcdonalds-logo-backlash?utm_source=DesignTAXI\&utm_medium = DesignTAXI\&utm_term=DesignTAXI\&utm_ content=DesignTAXI\&utm_campaign $=$ DesignTAXI

Racoma, B. (2019, January 11). How McDonald's Adapts Around the World. Retrieved April 10, 2020, from https://www.daytranslations.com/ 
blog/how-mcdonalds-adapts-aroundthe-world/

Schultz, E. J. (2019, June 12). More and more brands are creating Lions of their own. Retrieved April 7, 2020, from https://adage.com/article/ special-report-cannes-lions/moreand-more-brands-are-creating-lionstheir-own/2176511

Schmitt, B. (2011). Experiential marketing: how to get customers to sense, feel, think, act, and relate to your company and brands. New York: Free Press.

Smilansky, S. (2018). Experiential marketing: a practical guide to interactive brand experiences. New York: Kogan Page Ltd.

Terkan, R. (2014). Importance of Crea-tive Advertising and Marketing Ac-cording to University Students' Perspective. International Review of Management and Market-ing, 4(3), 239-246. Retrieved May 6, 2020 from https:// www.econjournals.com/index.php/ irmm/article/viewFile/882/pdf

Tovrljan, J. (2020, March). Coronavirus Logos. Retrieved March 29, 2020, from https://www.behance.net/gallery/93755381/Coronavirus-Logos

Turner Duckworth. (2019). McDon-ald's. Retrieved April 7, 2020, from https:// turnerduckworth.com/medonalds

Walansky, A. (2020, March 24). McDonald's gives its famous logo a makeover to promote social dis-tancing. Retrieved May 6, 2020, from https://www.today.com/food/mcdonald-s-changes-golden-arches-logo-amid-coronavirus-outbreak-t176653

Wheeler, A. (2017). Designing brand identity: an essential guide for the entire branding team. Hoboken, NJ: John Wiley \& Sons, Inc.

Wohl, J. (2020, March 23). McDonald's typography-driven campaign reminds people of drive-thru and de-livery during coronavirus. Re-trieved April 10, 2020, from https://adage. com/creativity/work/mcdonalds-typography-driven-campaign-reminds-people-drive-thru-and-delivery-during-coronavirus/2245711 